\title{
APPLICATION OF THE ELECTRICAL IMPEDANCE SPECTROMETRY FOR MONITORING WATER FLOW IN UNSATURATED SOIL
}

\author{
Tymoteusz Adam Zydroń ${ }^{\circledR}$, Andrzej Gruchot ${ }^{1}$, Jana Pařílková2 ${ }^{2}$ Zbyněk Zachoval ${ }^{2}$ \\ ${ }^{1}$ Faculty of Environmental Engineering and Land Surveying, University of Agriculture in Krakow, Al. Mickiewicza 24/28, 30-059 Kraków \\ ${ }^{2}$ Faculty of Civil Engineering, Brno University of Technology, Veveři street 331/95, 60200 Brno
}

\begin{abstract}
Aim of paper

The aim of research was to determine the sensitivity of the impedance spectrometry method (EIS) to changes in electrical resistance of soil caused by water infiltration.

Materials and methods

Two types of mineral soil were considered in the research: fine sand and coarse silty sand. The research was to determine basic geotechnical properties of both soils (filtration coefficient, soil-water characteristic curve) and water infiltration tests in a vertical soil column. These tests included measuring changes in electrical resistance of soil medium, which were compared with observations of the location of the wetting front and numerical calculations of water flow through the soil. Infiltration tests were run for three soil samples. The first was a sample of medium sand, the second - coarse silty sand, and the third - medium sand in the lower part and coarse silty sand in the upper part.
\end{abstract}

\section{Results and conclusions}

The results of tests of electrical resistance of soils subjected to infiltration process in vertical column confirmed the significant impact of water in soil medium on its electrical conductivity. It has been shown that a change in soil moisture from an air-dry state to full saturation leads to a reduction of soil resistance by almost three orders of magnitude.

Keywords: infiltration, soil, electrical impedance spectrometry

\section{INTRODUCTION}

Development of geophysical methods leads to their increasingly popularity in issues related to soil base recognition or assessment of technical conditions of earth engineering constructions (Bajda et al., 2013, Bacior et al., 2015, Zawadzki, 2015, Yilmaz and Koksoy, 2017, Zieher et al., 2017, Almadani et al., 2018), whereby particularly common are electro-resistance tests. In advantage of these methods is an ability to estimate the properties of soils from the earth's surface without the need to carry out invasive tests, and thus interfering with soil structure (Lech et al., 2016). Electro-resistance method assumes that soils are characterized by an ability to conduct electric current, but as is shown by Gruchot et al. (2018), Pařílková et al. (2018) this method is sensitive to relation between soil moisture and its saturation, as well as to concentration of possible soil and water contamination. As indicated by Lech and Garbulewski (2009), it is difficult to interpret the results of field tests and it requires knowledge on the impact that these factors have on soil electrical

凶e-mail: tymoteusz.zydron@urk.edu.pl 
resistance. Therefore, laboratory tests are usually performed to learn that.

In practice, measuring soil electrical resistance is conducted by the four electrodes method. The electric current is supplied to the soil through two electrodes, which excite the electric field, and the next two measure the difference in potential of this field (Lech et al., 2016). Knowing the difference between potential of electric field and current intensity as well as the distances between electrodes allows to determine the value of an apparent resistivity of the soil. This method is modified by using either a pair of EIS probes or a single probe.

Electrical resistance (or resistivity) of soils is essentially related to a degree of water saturation, which in natural conditions depends on intensity of precipitation and water infiltration rate in the soil. Some of the water, in result of capillary forces, is retained in the soil, and some feeds groundwater due to gravity.

The process of water infiltration in the soil is difficult to describe, because soil consists three-phases. There is a solid phase (grains and soil particles), a gas phase (air contained in the pores) and a liquid phase (liquid contained in the pores). It is assumed that water and air in the pores impede water flow. On the other hand, soil grains and gases do not conduct electricity, and only water (or liquid) allows the flow of electric charge. Thus, the main factor enabling electricity flow in the soil is electrolytic conductivity, which depends on an amount of water filling the pores, and thus on soil's moisture. Therefore, knowing the water volume in the soil pores is important to describe infiltration process and changes in electrical resistance.

Water volume in the pores is most often described by degree of saturation (water saturation):

$$
S_{r}=\frac{V_{w}}{V_{p}}=\frac{\theta}{n}
$$

given that:

$V_{w}$ - water volume in the pores [\%],

$V_{p}$ - pore volume [\%],

$\theta-$ volumetric moisture content [-],

$n$ - porosity [-].

Soil electrical resistance is an electrical variable expressing its ability to conduct electricity and a part of electrical impedance. The $R$ electrical resistance is determined by conductor properties:

$$
R=\frac{\rho \cdot l}{A}[\Omega]
$$

given that:

$\rho-$ resistivity (resistance) of conductor $[\Omega \mathrm{m}]$,

$l$ - length of conductor's wire [m],

$A$ - cross-sectional area of conductor $\left[\mathrm{m}^{2}\right]$.

Apart from the electrical conductivity of grains and air, the geometry of the conductor is regulated by a system of interconnected water particles in the soil. There is a strong correlation between degree of saturation $S_{r}$ and electrical resistance of the soil medium. Water captured in the soil practically does not conduct electrical current and is isolated from an environment, so it has virtually no influence on change in electrical resistance. This means that with a low degree of saturation, and thus low moisture content, the soil will display high electrical resistance.

Another factors affecting soil resistance are the temperature of water and the concentration of salt, because electrical resistance of water is correlated with changes in temperature and salt concentration. Every soil - with its water - has a different relation between a degree of water saturation and electrical resistance. So, there is no general rule and it always should be determined experimentally.

The aim of the research was to determine the sensitivity of the impedance spectrometry method (EIS) to changes in electrical resistance of soil caused by water infiltration.

\section{RESEARCH METHODOLOGY}

Two mineral soils were considered in research: fine sand and coarse silty sand. The research was to determine basic geotechnical properties of both soils (filtration coefficient, soil-water characteristic curve) and water infiltration tests in a vertical soil column. These tests included measuring changes in electrical resistance of soil medium, which were compared with observations of the location of the wetting front and numerical calculations of water flow through the soil.

Research on geotechnical properties of both soil types and preliminary investigations of the relation- 
ship between resistance and moisture content of both soils was conducted in a geotechnical laboratory of the Department of Hydraulic Engineering and Geotechnics; and the determination of soil retention was carried out in the laboratory of the Institute of Soil Science and Agrophysics of the University of Agriculture in Cracow (Poland). Tests of water permeability, infiltration and soil electrical resistance were carried out in the Hydrotechnical Laboratory of the Faculty of Civil Engineering of the Brno University of Technology (Czech Republic).

Particle-size distribution of soils was determined by a combined method, i.e. sieve for grains larger than $0.063 \mathrm{~mm}$, and hydrometric for smaller particles (PKNCEN ISO / TS 17892: 4), and specific gravity (particle density) using a pycnometer method (PKN-CEN ISO / TS 17892: 3). The parameters of compactability of coarse silty sand were recorded in the Proctor apparatus, in a cylinder with a volume of $2.2 \mathrm{dm}^{3}$ at a compaction energy of $0.59 \mathrm{~J} \cdot \mathrm{cm}^{-3}$ (PN-88 / B-04481: 1988), and medium sand with the vibratory method in a cylinder of about $0.5 \mathrm{dm}^{3}$ (PN-88 / B-04481: 1988).

Studies on the influence of volumetric moisture content on changes in the resistance of tested soils were carried out on samples compacted in a cylinder with a volume of $2.2 \mathrm{dm}^{3}$ to reach a porosity $\mathrm{n} \cong 0.4$. After compaction of samples and installations of EIS probes (see: Fig. 1), values of soil resistance were measured at volumetric moisture content of soil in a range from 0 to $0.20 \mathrm{~m}^{3} \cdot \mathrm{m}^{-3}$. Moisture content range was based on a necessity to limit the gravity of water leachate and its accumulation in the lower part of a sample, which is a frequent phenomenon occurring in mineral soils. The tests were aimed at an initial determination of a range of possible soil resistivity values. The EIS measuring probe (see: Fig. 1) comprised of two 5-channel measuring electrodes with a length of $22.5 \mathrm{~cm}$. Measuring electrodes formed a measuring probe in a pair with 5 vertical measuring segments each $2.5 \mathrm{~cm}$ high.

Water retention tests for soils were run with the porous plate method in pressure chambers in a range of $\mathrm{pF}$ potentials from 1 to 4.2 , which corresponded to a height of matric suction (vacuum pressure height) from 1 to $15484 \mathrm{~cm}$, by drying. For each vacuum pressure value adopted, a test was carried out until the mass of samples was stabilized, which was then converted into volumetric moisture content $(\theta)$. Two series of measurements were taken for each soil. Results obtained during the study were described by van Genuchten formula (1980):

$$
\theta=\theta_{r}+\frac{\theta_{s}-\theta_{r}}{\left[1+\left(\alpha \cdot\left(u_{a}-u_{w}\right)\right)^{n_{v G}}\right]^{m}}
$$

given that:

$$
\begin{array}{ll}
u_{a} & - \text { air pressure in the pores, } \\
u_{w} & - \text { water pressure in the pores, } \\
\theta_{s} & - \text { volumetric moisture content at full sa- } \\
& \quad \text { turation of soil pores [-], } \\
\theta_{r} & - \text { residual volumetric moisture content, } \\
\alpha, \mathrm{n}_{v G}, \mathrm{~m}- & \text { constant equations, where }
\end{array}
$$

The parameters determined by the equation (3) were used for numerical calculations of infiltration.

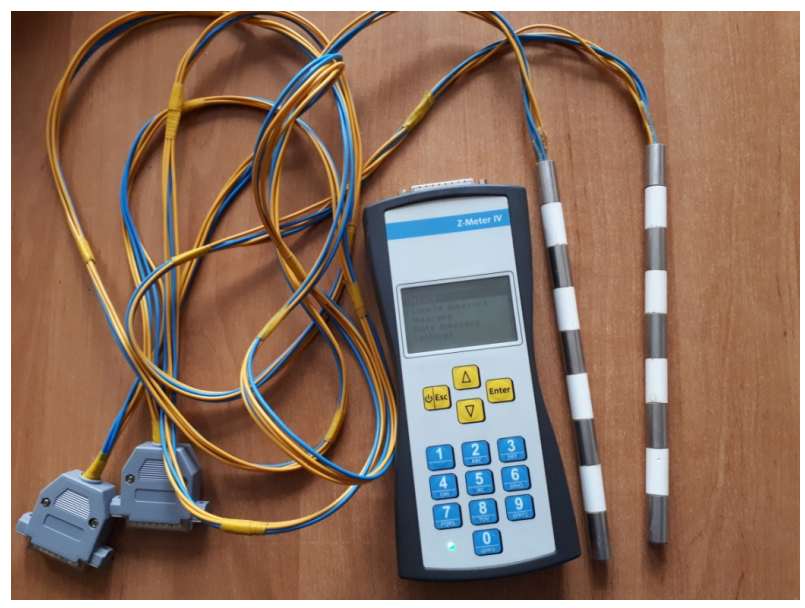

Fig. 1. View of Z-Meter.IV apparatus and EIS measuring electrodes (photo A. Gruchot)

Water permeability tests were carried out in a permeameter, which can work in a gravitational and pressure system. In the case of a gravitational system, a height of a hydraulic drop recorded on a piezometric tube panel (see: Fig. 2) is regulated by a variable height of a water tank supplied with a pump. If higher pressures are required, the device can be operated in pressure mode. It can reach up to $60 \mathrm{~m}$ of overpressure. Due to a wide range of working pressures, the apparatus can be used to test water permeability of permeable 

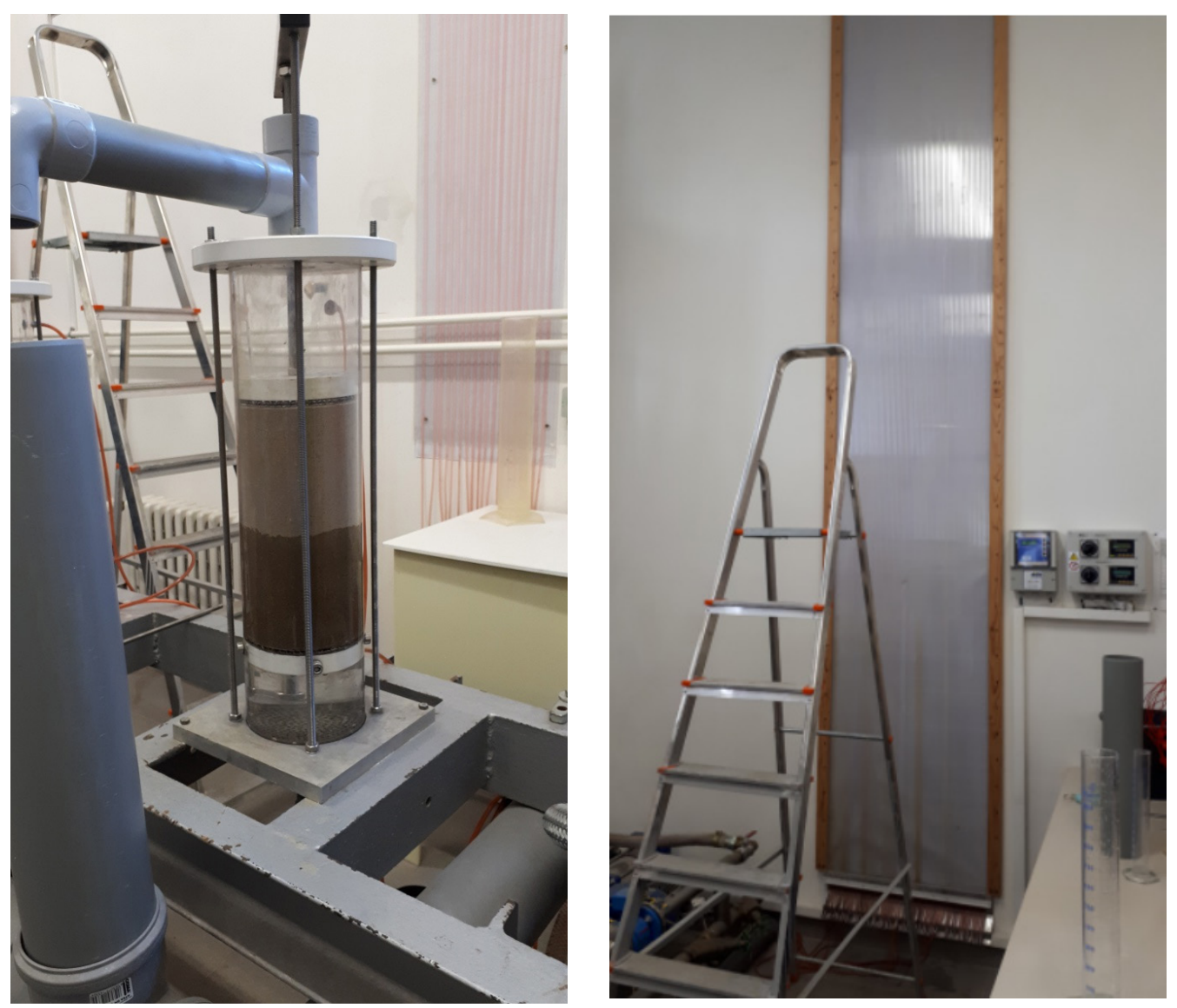

Fig. 2. View of a sample of medium sand during the test (a) and control panel of piezometric tubes (b) (photo A. Gruchot)

non-cohesive soils, but also low-permeable cohesive soils. Filtration coefficient was determined thorough samples with a diameter of $12.3 \mathrm{~cm}$ and a height of $24.6 \mathrm{~cm}$ with water flow from the bottom up at high drops and values of hydraulic gradient in a range 1-6. Samples of medium sand were vibrationally compacted to obtain density index $I_{S}=0.95$ and 1.00 (respectively with porosity $n=0.35$ and 0.32 ), and coarse silty sand mechanically to obtain $I_{S}=0.90$ and 0.95 (respectively with a porosity of $n=0.30$ and 0.26 ). The degree of saturation for medium sand was slightly above 0 , and for coarse silty sand was 0.12 on average.

Infiltration tests, with changes in electrical resistance caused by water flow through the soil, were carried out in a cylinder made of organic glass with an internal diameter (sample) of $12.3 \mathrm{~cm}$ and a height of $70.5 \mathrm{~cm}$ (see: Fig. 3). Infiltration tests were carried out for three soil samples. In the first case it was a sample of vibrationally compacted medium sand with a moisture content of $0.5 \%$, the porosity of which was 0.33 . The second sample consisted of coarse silty sand mechanically compacted at a moisture content of about $4.8 \%$, with a porosity of 0.28 . As for the third sample, its lower part, $36 \mathrm{~cm}$ in height, consisted of medium sand with a porosity of 0.33 and the upper part - coarse silty sand - with a porosity of 0.28 at the same height. The degree of saturation for medium sand was slightly above 0 , and for coarse silty sand was 0.3 on average.

In the lower part of the cylinder there is a filter consisting of a mesh and a geosynthetic with a higher hydraulic conductivity than the tested material, so that they do not affect the process of water infiltration. Another cylinder with the same diameter and dozing infiltrating water was attached to the cylinder with the soil sample.

Electrical resistance measuring electrodes were stainless steel screws mounted in a cylinder wall. 


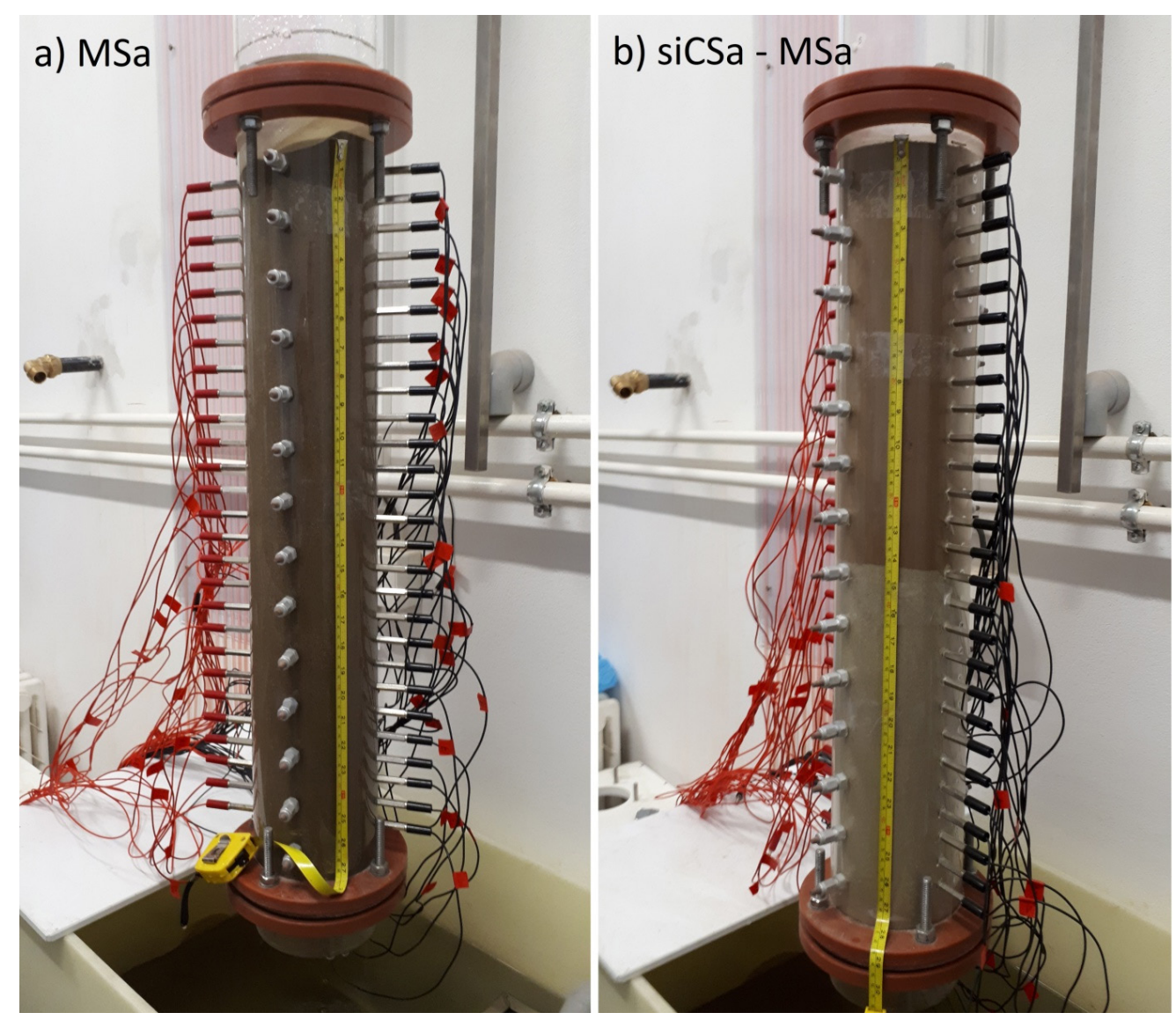

Fig. 3. A view of a sample of medium sand and a sample of coarse silty sand alternately with medium sand during a resistance test (visible measuring probes) (photo A. Gruchot)

Two electrodes on the opposite sides of the cylinder formed one sensor - their total number was 27 . Vertical spacing of the sensors was $2.5 \mathrm{~cm}$. The first sensor was placed $2.5 \mathrm{~cm}$ below the upper surface of the soil. Each sensor electrode was releasably connected to an insulated conductor through a single-pole plug. The switch with 32 measuring points was connected to the Z-Meter.IV recorder (see: Fig. 1). Measured signal was recorded in a form of real and imaginary components of electrical impedance and simultaneously stored in the device's memory. Further processing of the test results was performed in an Excel spreadsheet.

During the tests, changes in the mass of soil samples in an infiltration column were monitored, as well as the volume of water discharged in order to maintain a constant water level above the surface of samples and the position of the wetting front in the column. Measurements were being taken until a filtration flow was found in a sample base or a visible moistness of a filter in the lower part of a sample. Based on the research, numerical calculations of infiltration were made in order to show the relation between changes in water pressure in the pores and soil resistance (resistivity) due to changes in moisture content (degree of saturation) of the soil caused by water flow. Calculations were made in the GeoStudio program. The values of hydraulic parameters of soils are characterized by high variability (Zawisza and Klimek, 2016, Zieher et al., 2017), and therefore both the values of filtration coefficient and the parameters of the van Genuchten formula were calibrated to obtain consistency between the wetting front observed during the tests and the results of numerical calculations. 


\section{TEST RESULTS}

\section{Geotechnical parameters of analysed soils}

The research was conducted for two types of soil a multi-fraction, well-grained coarse silty sand and a single-fraction, poorly grained medium sand (see: Fig. 4). The basic geotechnical characteristics of tested soils are presented in Table 1.

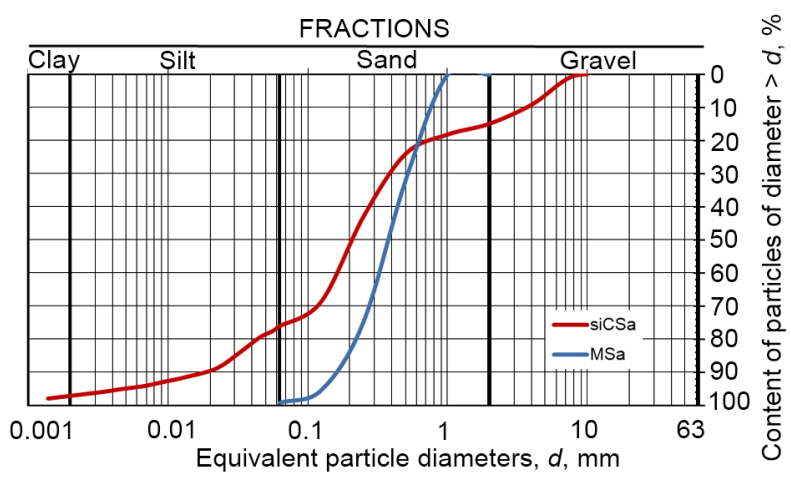

Fig. 4. Particle size distribution curves of tested soils

Table 1. Geotechnical properties of tested soils

\begin{tabular}{|c|c|c|}
\hline Parameter & Value & \\
\hline $\begin{array}{l}\text { Fraction content [\%]: } \\
\text { gravel, Gr. } 63-2 \mathrm{~mm}\end{array}$ & 15.0 & 0 \\
\hline sand, Sa $2-0.063 \mathrm{~mm}$ & 61.0 & 92.8 \\
\hline silt, Si $0.063-0.002 \mathrm{~mm}$ & 21.1 & \multirow{2}{*}{0.8} \\
\hline clay, $\mathrm{Cl}<0.002 \mathrm{~mm}$ & 2.9 & \\
\hline $\begin{array}{l}\text { Name acc. to [PN-EN ISO } 14688- \\
2: 2006]\end{array}$ & $\begin{array}{c}\text { Coarse } \\
\text { silty sand } \\
\text { (siCsa) }\end{array}$ & $\begin{array}{c}\text { Medium } \\
\text { sand } \\
(\mathrm{MSa})\end{array}$ \\
\hline Uniformity coefficient [-] & 15.1 & 2.7 \\
\hline Coefficient of curvature [-] & 3.0 & 1.1 \\
\hline Density of solid particles $\left[\mathrm{g} \cdot \mathrm{cm}^{-3}\right]$ & $2.71 *$ & 2.65 \\
\hline $\begin{array}{l}\text { Maximum dry density of solid } \\
\text { particles }\left[\mathrm{g} \cdot \mathrm{cm}^{-3}\right]\end{array}$ & 2.12 & \\
\hline Optimum moisture content [\%] & 7,8 & \\
\hline $\begin{array}{l}\text { Minimum and maximum dry } \\
\text { density of solid particles }\left[\mathrm{g} \cdot \mathrm{cm}^{-3}\right]\end{array}$ & & $\begin{array}{l}1.49 \\
1.81\end{array}$ \\
\hline
\end{tabular}

Explanation: for fraction lower than $0.063 \mathrm{~mm}$.

\section{Hydraulic properties of tested soils}

Filtration coefficient is a parameter that describes a capability of soil medium to allow water flow through. It largely depends on soil granulation, its porosity, mineral composition, moisture content and shape of particles surface (Cadergen, 1997, Head and Epps, 2011). From the point of view of engineering practice, it is particularly important to adequately describe the phenomenon of water flow in the soil and to correctly determine its filtration coefficient. There are three basic methods of testing filtration coefficient - field, laboratory and empirical method, but it is widely considered that values obtained from tests based on actual physical flow of water through the soil (field and laboratory methods) are the most accurate.

Studies showed a significant impact of compaction and hydraulic gradient on obtained values of permeability coefficient (see: Fig. 5). In general, as the hydraulic gradient grows - for both values of soils' compaction - the values of permeability coefficient increase, on average by 0.5 orders of magnitude (see: Fig. 5). When comparing both soils, it should be pointed out that filtration coefficient of coarse silty sand was on average 2 orders of magnitude lower than of medium sand. Filtration coefficient values, obtained at higher densities for both soils, were lower by 0.3 to 0.5 order of magnitude than for lower densities. When comparing the recorded values of permeability to granular composition of tested soils, and in particular to the content of silty and sand fractions, it can be stated they are typical for this type of soils (Pazdro and Kozerski, 1990).

On the basis of registered retention properties (Fig. 6) of both soils, the values of van Genuchten function parameters were calculated. For medium sand these were $-\alpha=0.05 \div 0.08 \mathrm{~cm}^{-1}$ and $n_{v G}=1.3$, and for coarse silty sand $-\alpha=0.05 \div 0034 \mathrm{~cm}^{-1}$ and $n_{v G}=1,2 \div 1,55$. The obtained values of the parameter $\alpha$ were close to the values given for sandy and silty soils in the literature (Lu and Griffiths, 2004, Lu and Godt, 2008). Whereas, the values of the parameter $n_{v G}$, typical for silty and clay soils, were low.

\section{Influence of moisture on electrical resistance of soil}

Tests using the EIS method require calibration measurements, which are supposed to find the appropriate frequency of electrical impedance components mea- 


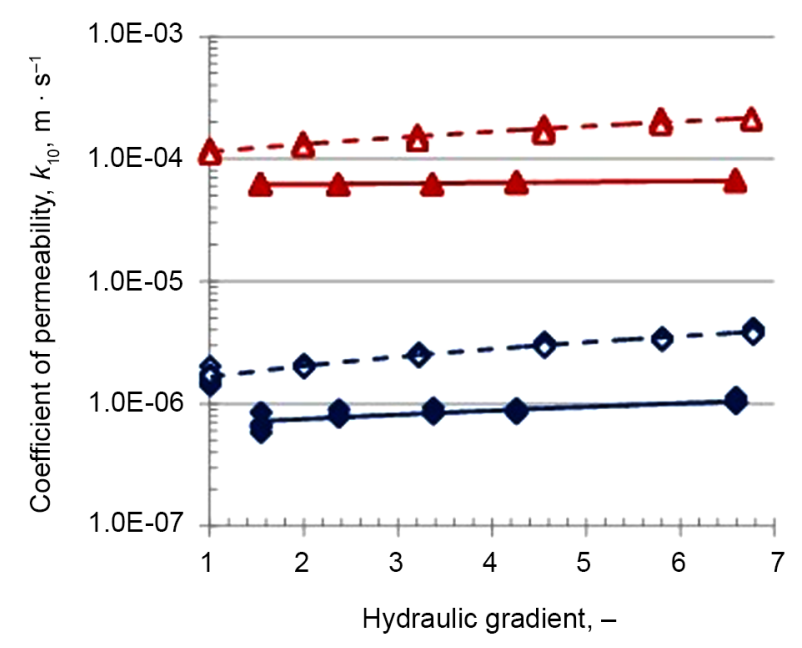

$\diamond$ siCSa, Is $=0.90(n=0.30) \diamond \operatorname{siCSa}, I s=0.95(n=0.26)$

$\Delta \mathrm{MSa}, I s=0.95(n=0.35) \quad \Delta \mathrm{MSa}, I s=1.00(n=0.32)$

Fig. 5. The dependence of filtration coefficient of tested soils on hydraulic gradient

surement. In the presented research, calibration was performed in measurement signal frequency range from 1500 to $4000 \mathrm{~Hz}$. For medium sand a frequency of 3700 $\mathrm{Hz}$ was assumed, which matched the highest value of electrical resistance (see: Fig. 7). However, for coarse silty sand, the assumed frequency was $2500 \mathrm{~Hz}$, which was the highest reactance value (X), as in case of resistance (R) this value was not clearly stated.

Figure 8 presents the results of resistance measurements of tested soils depending on volumetric moisture content. Received dependences indicate a significant influence of moisture content on resistance, while the impact being clearly nonlinear, which is typical in soil resistance studies (e.g. Merritt et al., 2016; Alamrya et al., 2017; Cardoso and Dias, 2017; Bertermann and Schwarz, 2018) and may indicate a relation between soil resistance and retention properties (Cardoso and Dias, 2017). It was noticeable in the conducted research that extreme values of soil resistivity differ by three orders of magnitude, which is confirmed by Zieher et al. (2017). It was also found that in volumetric moisture content range from 0.1 to 0.2 [-] coarse silty sand was characterized by lower resistivity values, which was due to higher amount of fine (silty and clay) fractions in relation to medium sand.

Results of research on electrical resistance of medium sand and coarse silty sand during water infiltration in a vertical column are shown in Figure 9-10. It is indicated that as the process of water infiltration proceeds, soil resistivity values are reduced, which a)

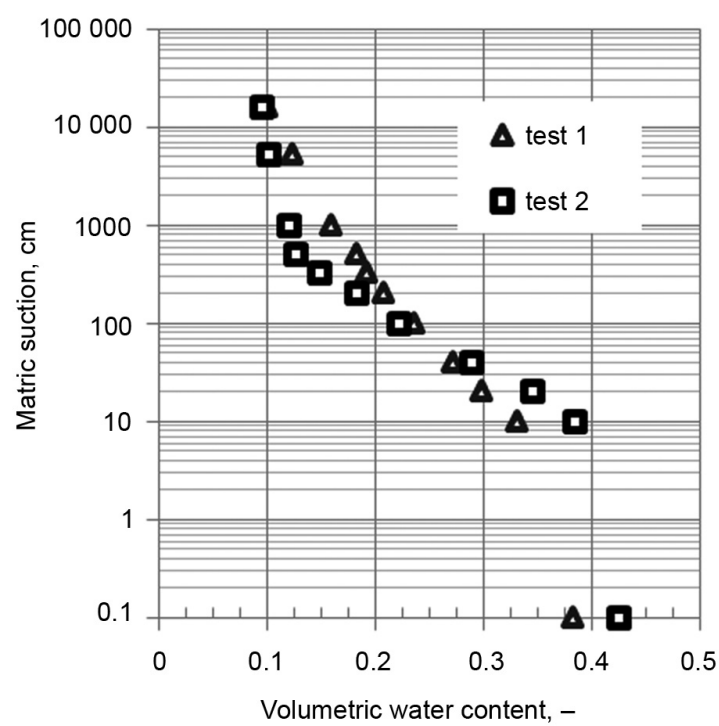

b)

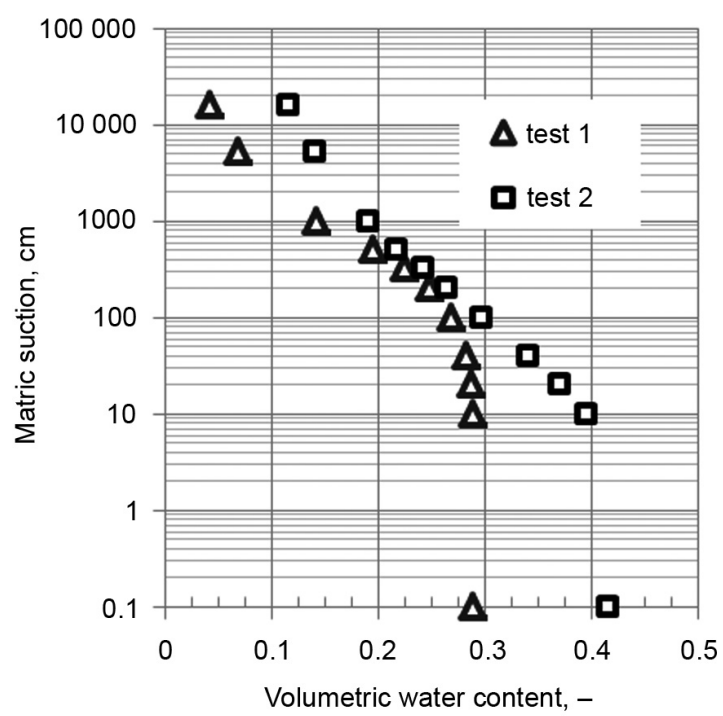

Fig. 6. Retention characteristics of medium sand (a) and coarse silty sand (b) 

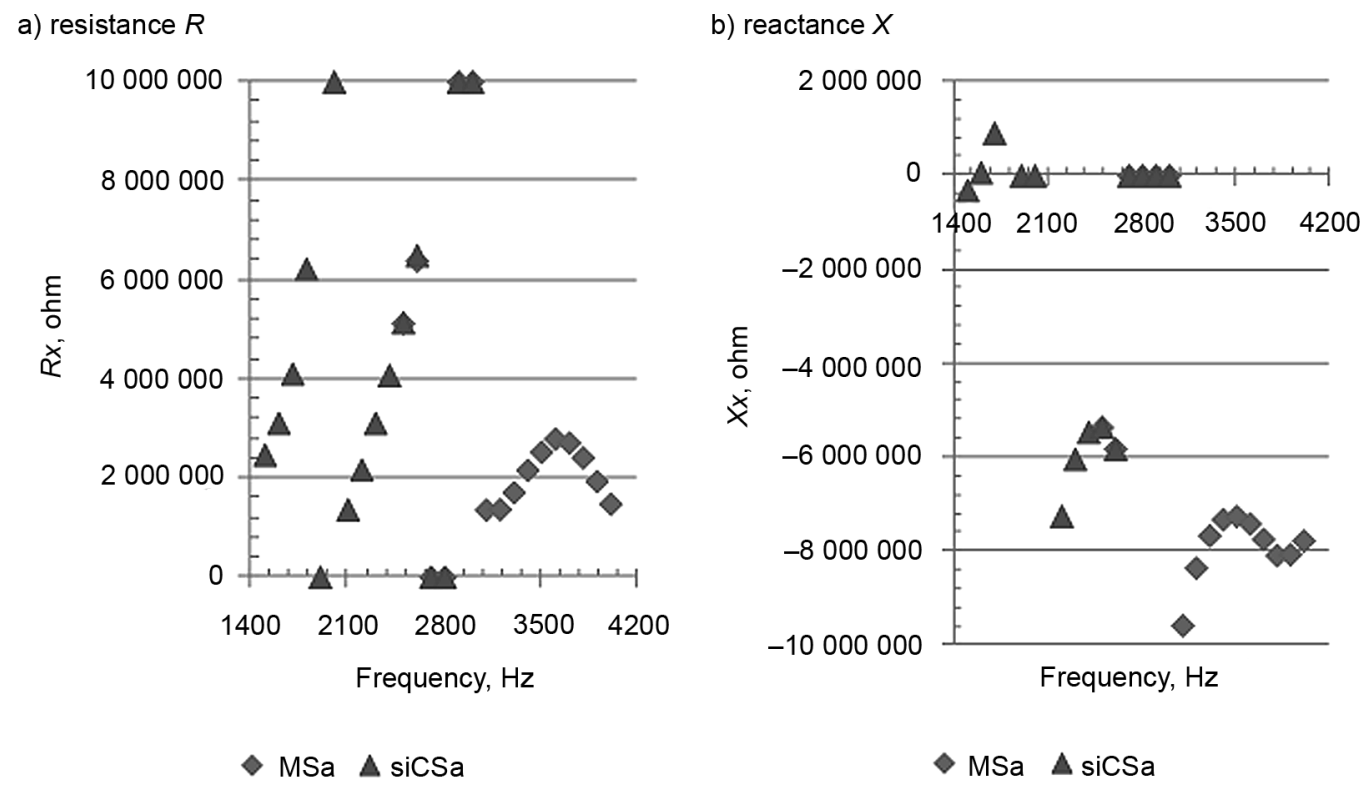

Fig. 7. The dependence of resistance and reactance of tested soils on frequency in calibration process of measurement probes

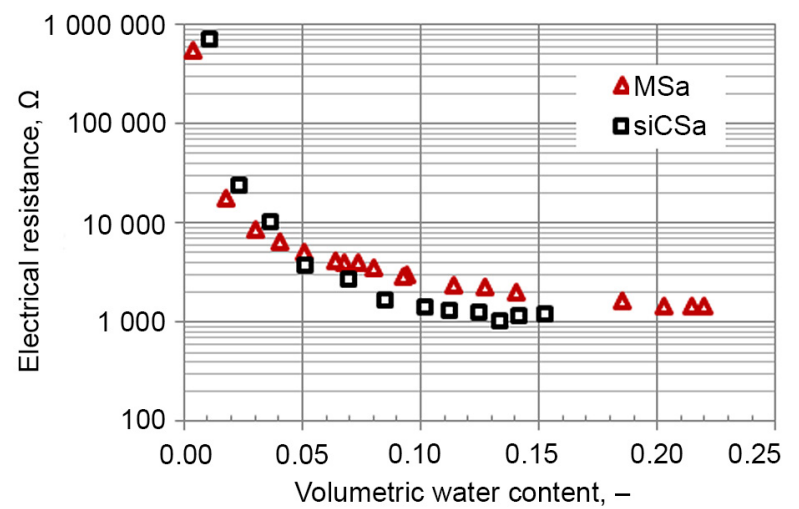

Fig. 8. Electrical resistance vs. volumetric moisture content of tested soils

means that the wetting front moves towards the sample base. Especially for medium sand (see: Fig. 9a) the boundary between saturated zone and dry soil is noticeable. For comparison, numerical calculations simulating the conducted tests were performed (see: Fig. 9b) showing piston nature of infiltration process. However, it should be pointed out that some differences in a position of the wetting front between conducted tests and numerical calculations. These changes may result in slight discrepancies between test conditions and those adopted for calculation. As for coarse silty sand (see: Fig. 10a), there were also significant changes in soil resistivity caused by infiltration process, and their character is in large part similar to the results of numerical calculations (see: Fig. 10b).

It should be noted that the minimum resistance values obtained during the research are clearly greater than those recorded from preliminary tests shown in Figure 8 . This may be caused by different dimensions of soil samples (cross-section area, height) as well as spacing and dimensions of measuring electrodes. Obtained resistance values include very wide range of values, posing some difficulties in their interpretation. Therefore, the test results have been developed in a form of logarithmized values, which is shown in Fig. 11 for medium sand. They indicate existence of a zone of rapid changes in soil resistivity, which can be identified with a wet zone or changes in wetting front position. However, electrical resistance values converted this way are not universal. For this reason, results of electrical resistance values of tested soils had to be interpreted by the aid of calculating relative reduction of soil resistance in accordance with the proposal given by Zieher et al. (2017): 
a)

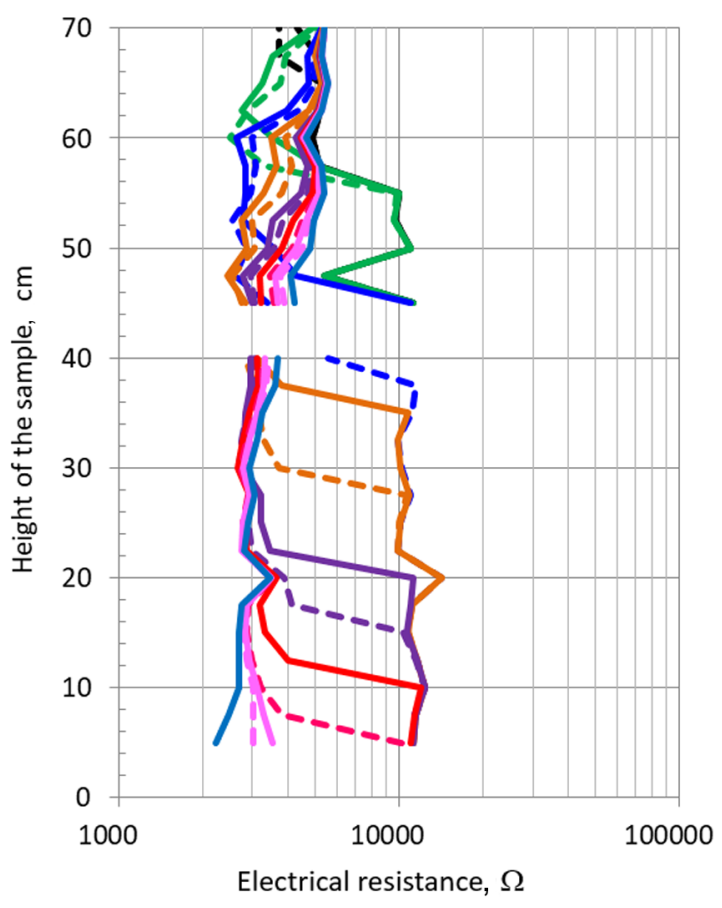

b)

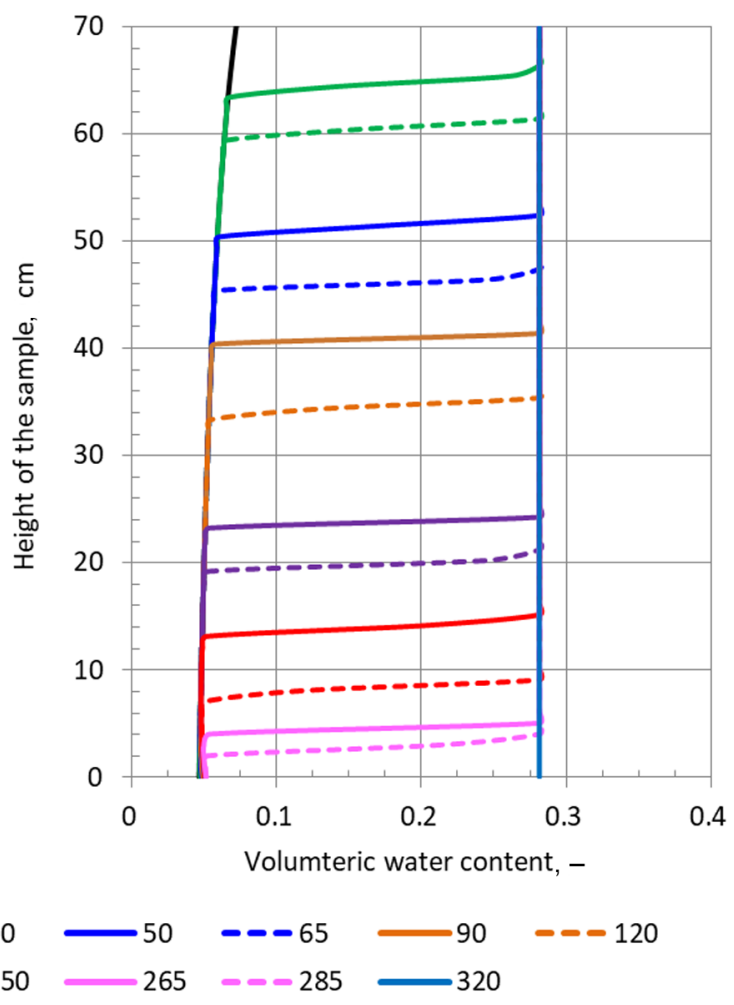

Fig. 9. Results of measurements of electrical resistance in infiltration column (a) and numerical calculations of changes in volumetric moisture content (b) of medium sand in effect of water infiltration

$$
R R=\frac{R_{x i}}{R_{\text {ref }}}-1
$$

given that:

$$
\begin{aligned}
R_{x i}- & \text { soil resistance in time " } \mathrm{i} \text { ", } \\
R_{\text {ref }}- & \text { reference soil resistance, which was deter- } \\
& \text { mined before infiltration tests. }
\end{aligned}
$$

Figures $12 \mathrm{a}-14 \mathrm{a}$ present results of calculations of relative reduction of electrical resistance (RR) of tested soils as a function of time and sample height, and Figures $12 \mathrm{~b}-14 \mathrm{~b}$ show results of changes in the wetting front position.

Relative resistance values of medium sand ranged from -0.9 to 0.1 (see: Fig. 12a) indicating significant changes in the wetting front position during the research. This correlation coincided with the results of an observation of the wetted zone position in infiltration column (see: Fig. 12b). Water flow occurred in a sample of medium sand after about 19 minutes. On the other hand, relative resistance reduction calculations show that in the initial stage of the test at the bottom of the sample there was a local increase in soil resistance $(\mathrm{RR}>0.0)$. This may indicate a reduction in soil porosity due to weight increase of the higher part of the soil sample caused by presence of water in soil pores. Similar correlations are presented by Bertermann and Schwarz (2018). They demonstrated that with increasing load of a sample with constant moisture content and a decrease in soil porosity, its electrical conductivity increases.

As for coarse silty sand, no water outflow was found at the base of infiltration column, only soil wetting (see: Fig. 13b). The time for water to flow through the soil was estimated at about 280-300 minutes. Relative soil resistance reduction values were fit in a much smaller range than in case of medium 
a)

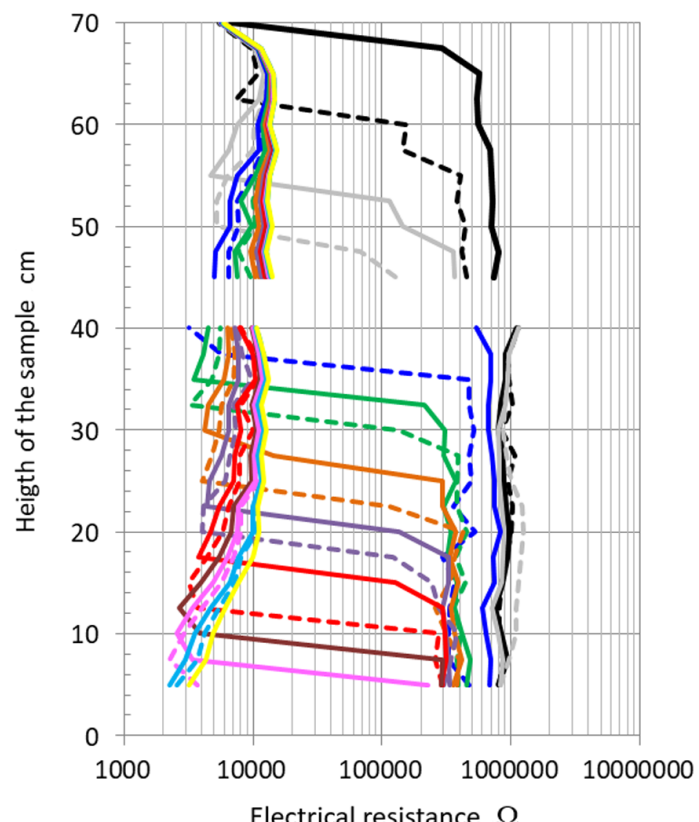

b)

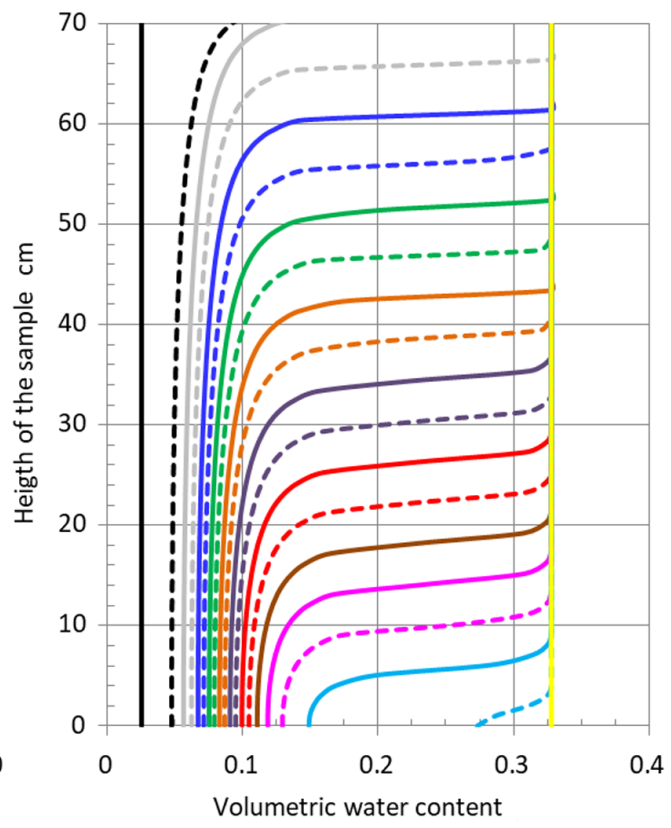

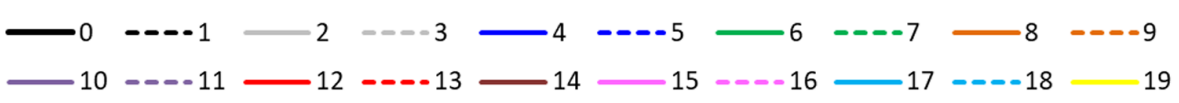

Fig. 10. Results of measurements of electrical resistance in infiltration column (a) and numerical calculations of changes in volumetric moisture content (b) of coarse silty sand in effect of water infiltration

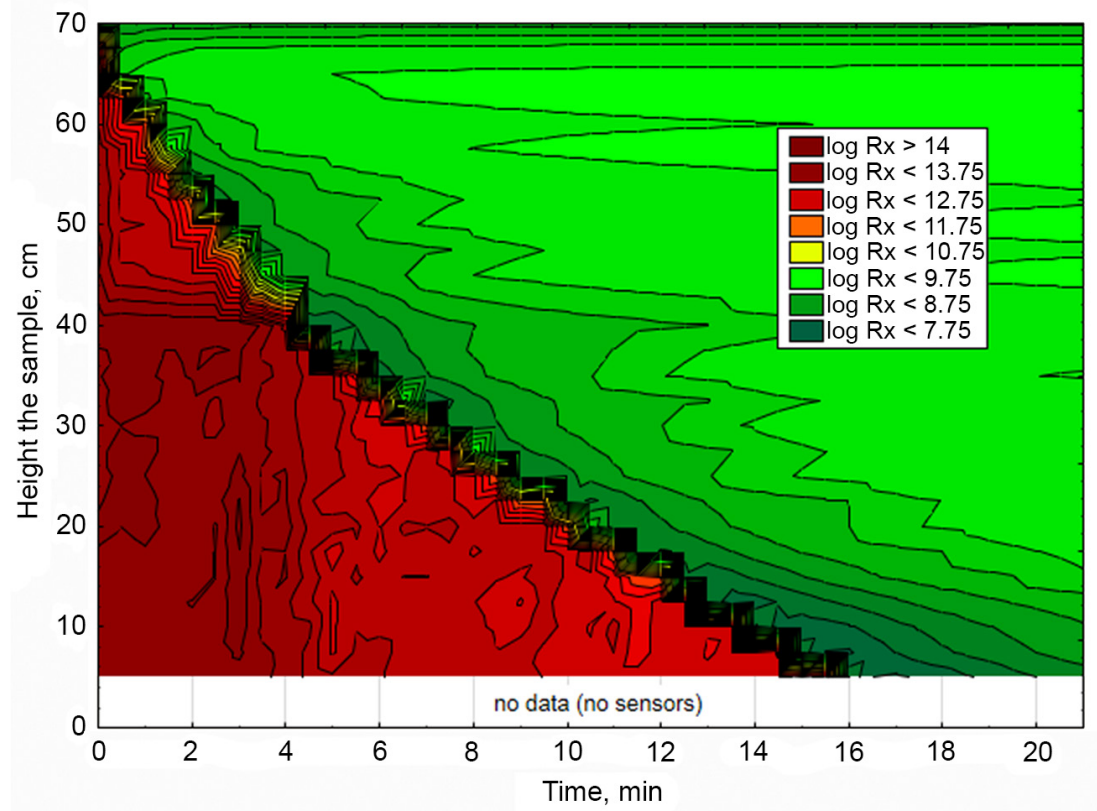

Fig. 11. Results of medium sand resistance measurements presented on a logarithmic scale 
a)

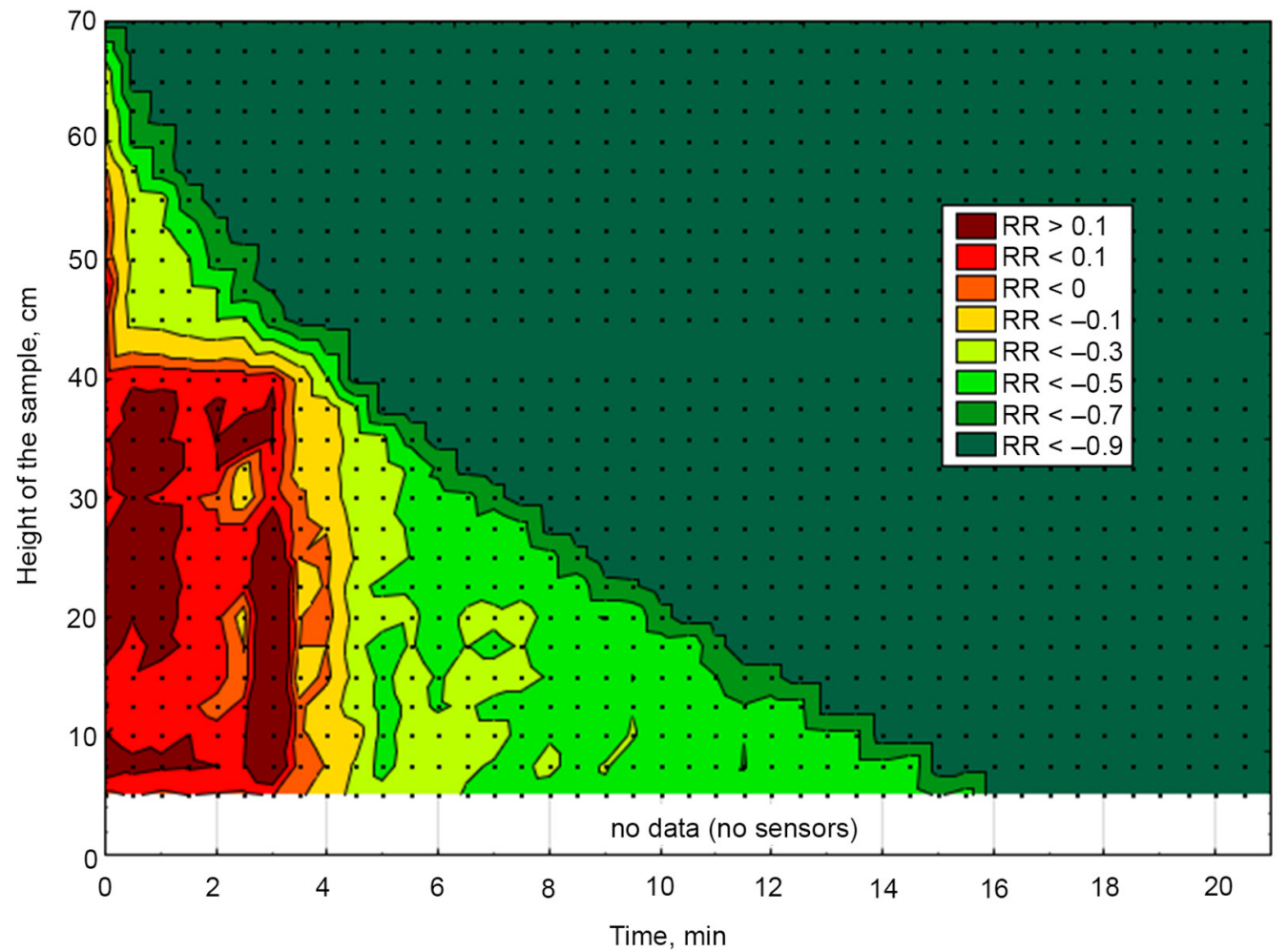

b)

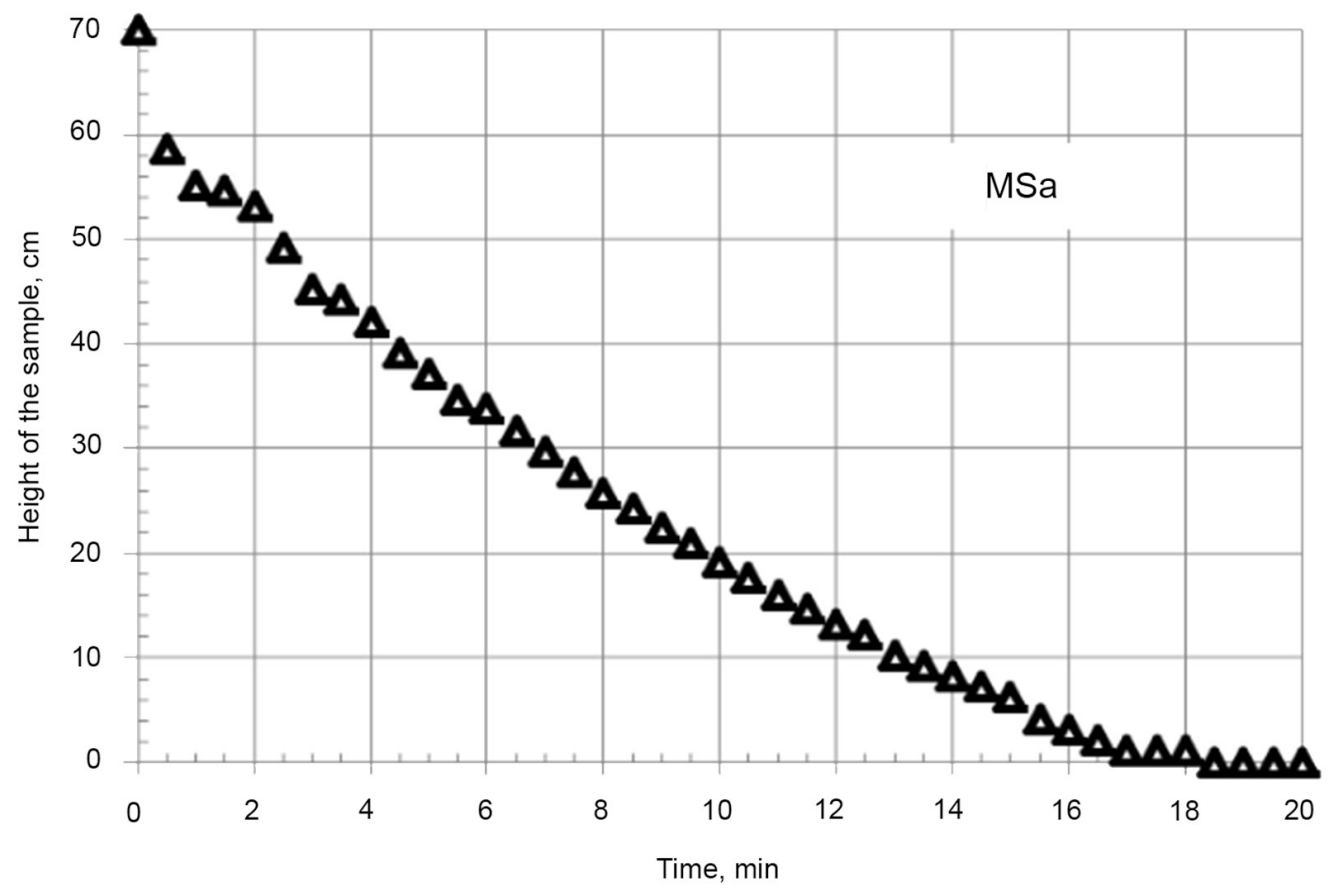

Fig. 12. Results of calculations of relative reduction of resistance (a) and of observation of the wetting front position (b) in infiltration column for medium sand 
sand tests - and ranged from -0.81 to 0.05 , which was related to relatively high initial volumetric moisture content of soil $(\theta=0.08)$. Relative soil resistance reduction values in a range from -0.7 to -0.5 seem to be in accordance with the wetting front position (see: Fig. 13a), which was consistent with results of observation of movement of wetted zone in infiltration column (see: Fig. 13b).

Results of water infiltration tests in stratified sample (consisting of a layer of coarse silty sand above and medium sand below) are shown in Figure 14. In the case of this test, wetting of sample base occurred after about 260 minutes, so it took slightly longer time than implied by observation of the wetting front. Relative resistance reduction values (RR) ranged from -0.99 to 1.33 , essentially less than 0.3 , and only the near-surface area of the sample being over 1.0. High values may be connected to damaging the sample surface caused by adding water. After the test was finished, at the height of about $0.7 \mathrm{~m}$ visible deformations of the sample surface were found in the boundary zone. The measuring sensor was located there about $1 \mathrm{~cm}$ above the sample surface. The second zone with high values of relative resistance reduction parameter $(\approx 0.7)$ was located about $7-12 \mathrm{~cm}$ below the upper surface of the sample. This zone marked its presence at the end of the test, after the zone of high values of relative resistance reduction has emerged near the surface.

Tests of stratified sample indicate a development of two zones that differ from each other in relative reduction values of soil resistance, which may result from geotechnical parameters of both soils. Lower values of relative resistance reduction (RR) obtained in the upper part of the sample (coarse silty sand) are caused by higher initial volumetric moisture content $(\theta=0.08)$, not by the lower layer $(\theta=0.02)$, i.e. medium sand. In the medium sand layer the lowest values of relative resistance reduction were $R R=$ -0.994 , indicating that resistance values during in- filtration process decreased by almost 2.5 orders of magnitude. The results of field tests incl. Alambry et al. (2017), Zieher et al. (2017), Vanella et al. (2018) indicate that changes in soil electrical resistivity values caused by water flow in the soil in relation to an initial resistivity value usually do not exceed $50 \%$, which corresponds to relative resistivity reduction $\mathrm{RR}=-0.5$. Zieher et al. (2017) while conducting soil tests on a subjected to watering alpine slope, registered changes in relative reduction of resistivity (RR) by a maximum of 0.2 , while assuming that changes in the RR parameter at rate of 0.03 are within an accuracy range of the measurement method.

\section{CONCLUSIONS}

The results of tests of electrical resistance of soils subjected to infiltration process in vertical column confirmed a significant impact of water in soil medium on its electrical conductivity. It has been shown that a change in soil moisture from an air-dry state to full saturation leads to a reduction of soil resistance by almost three orders of magnitude. Generally, the amount of resistance reduction has a significant relation to the initial moisture content of the soil - the higher the soil moisture content value, the lower the resistance reduction value.

Test results have proven a relatively good convergence between the observed wetting front position and measured values of soil resistance, thus confirming the usefulness of the tested measurement method for monitoring water circulation in the soil, indicating at the same time some limitations and difficulties in interpretation of test results. Despite obtaining measurable values, resistance measurements are essentially of a qualitative nature, and a quantitative interpretation of physical processes occurring in the soil requires additional support by means of other calculation methods or a use of additional measurement methods. 
Zydroń, T. A., Gruchot, A., Pařílková, J., Zachoval, Z. (2019). Application of the electrical impedance spectrometry for monitoring water flow in unsaturated soil. Acta Sci. Pol., Formatio Circumiectus, 18 (2), 93-108. DOI: http://dx.doi.org/10.15576/ASP.FC/2019.18.2.93

a)

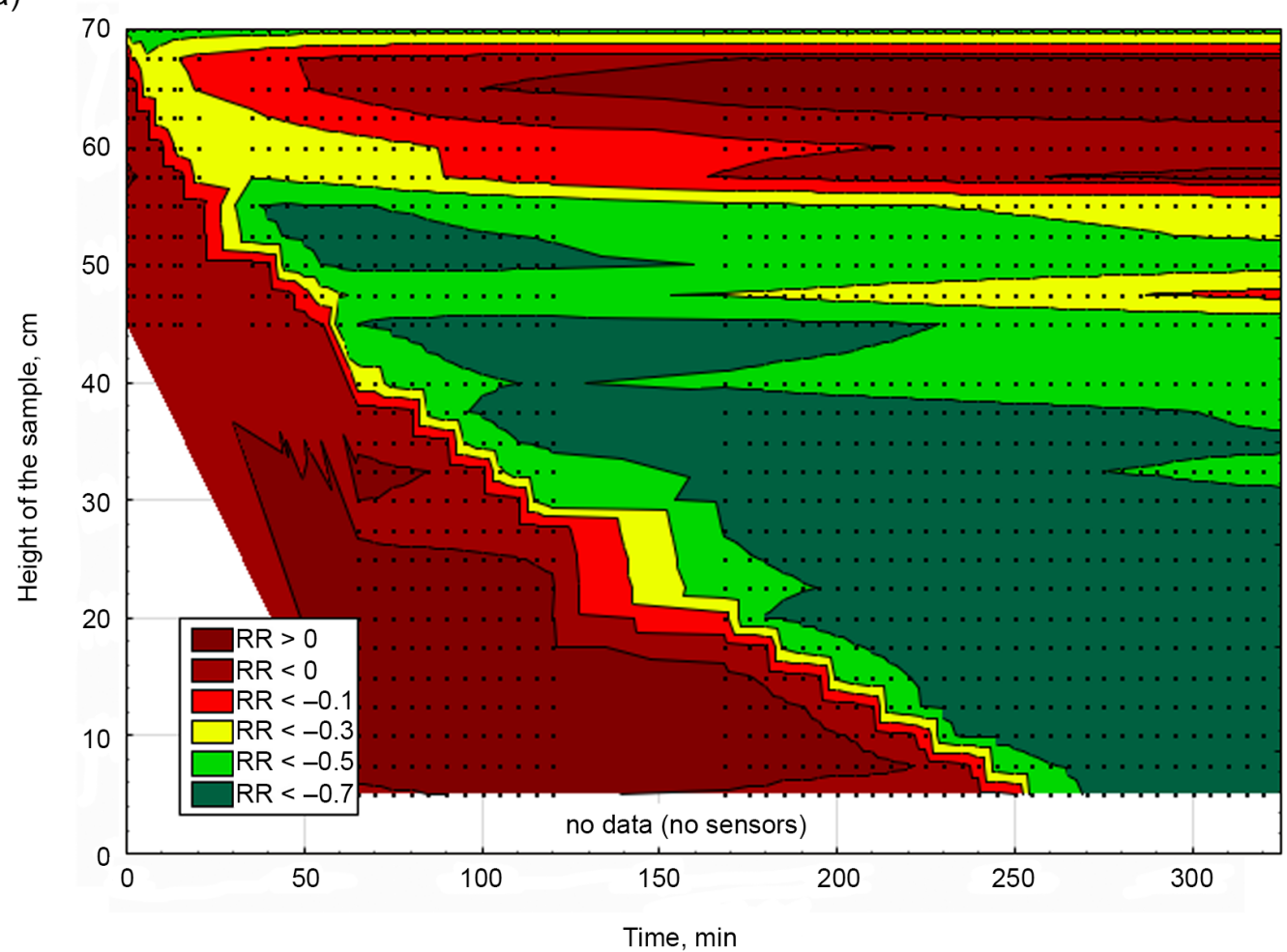

b)

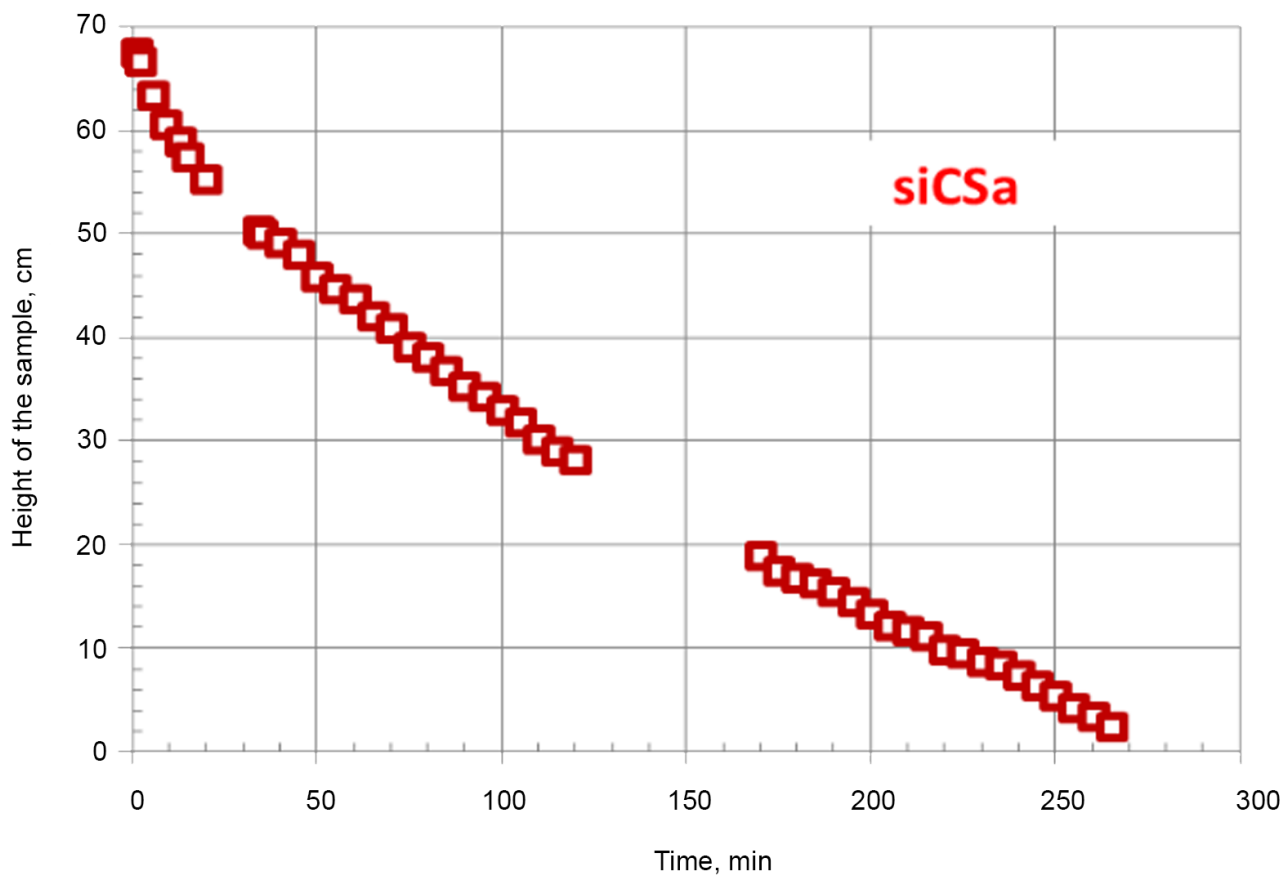

Fig. 13. Results of calculations of relative reduction of resistance (a) and of observation of the wetting front position (b) in infiltration column for coarse silty sand 
a)
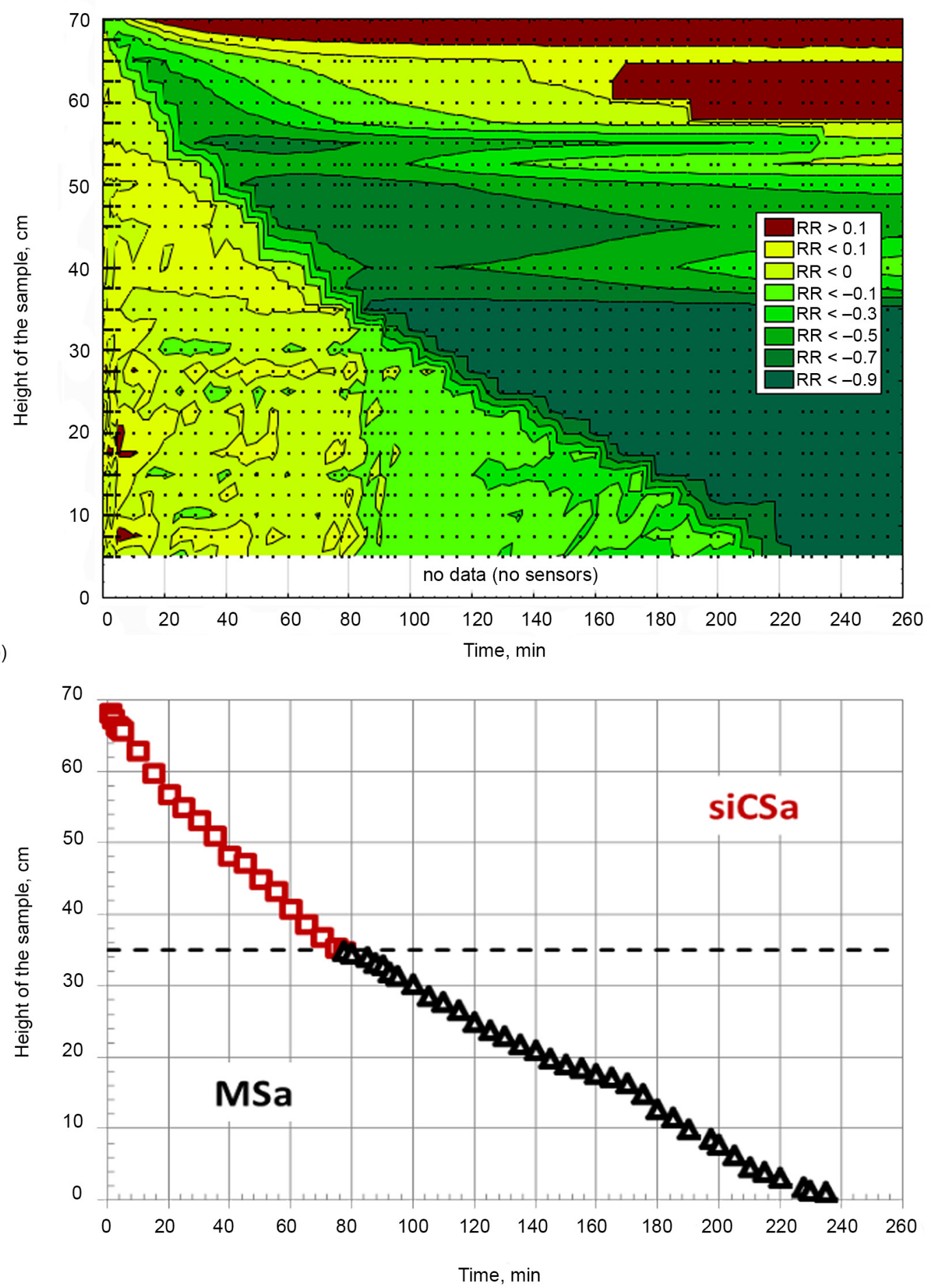

Fig. 14. Results of calculations of relative reduction of resistance (a) and of observation of the wetting front position (b) in infiltration column for stratified sample 


\section{REFERENCES}

Almadani, S., Elkhedr Ibrahim, E., Hafez, M., Alfaifi, H., Alharbi, T., Abdelrahman, K., Abdel-Motaal, E. (2018). Geotechnical investigation of the El-Elb dam site, northwest Riyadh, Saudi Arabia, using 2D resistivity and ground-penetrating radar techniques. Arabian Journal of Geosciences, 11:33. DOI: https://doi.org/10.1007/ s12517-017-3353-x

Alamrya, A.S., van der Meijde, M., Noomen, M., Addink, E.A., van Benthem, R., de Jong, S.M. (2017). Spatial and temporal monitoring of soil moisture using surface electrical resistivity tomography in Mediterranean soils. Catena, 157, 388-396.

Bacior, S., Nawrocki, W. Piasek, Z., (2015). Georadarowa ocena konstrukcji nasypów drogowych. Acta Sci. Pol. Formatio Circumiectus, 14(2), 17-24

Bajda, M., Lech, M., Kronik, K. (2013). Wykorzystanie powierzchniowych badań elektrooporowych do oceny stanu technicznego budowli ziemnych. Przegląd Naukowy - Inżynieria i Kształtowanie Środowiska, 60, 117-125

Bertermann, D., Schwarz, H. (2018). Bulk density and water content-dependent electrical resistivity analyses of different soil classes on a laboratory scale. Environmental Earth Sciences, 77: 570.

Cadergen, R. (1997). Seepage, Drainage and Flow Nets. New York: John Wiley and Sons, 467.

Cardoso, R., Dias, A.S. (2017). Study of electrical resistivity of compacted kaolin basend on water potential. Engineering Geology, 226, 1-11.

Gruchot, A., Zydroń, T., Pařilková, J., Zachoval, Z., Cholewa, M., Koś, K. (2018). Wykorzystanie spektrometrii impedancyjnej do monitorowania przepływu filtracyjnego przez nasypy hydrotechniczne. Acta Sci. Pol. Architectura, 17(1), 55-65, DOI: 10.22630/ASPA.2018.17.1.6.

Head, K., Epps, R. (2011). Manual of soil laboratory testing. Vol. 2. Permeability, shear strength and compressibility test. Whittles Publishing, Dunbeath Mill.

Lech, M., Bajda, M., Markowska-Lech, K., Skutnik, Z. (2016). Przykłady zastosowania pomiarów oporności elektrycznej w geotechnice środowiskowej. Zeszyty Naukowe Instytutu Gospodarki Surowcami Mineralnymi i Energią Polskiej Akademii Nauk, 93, 83-94.

Lech, M., Garbulewski, K. (2009). Określanie porowatości gruntów niespoistych na podstawie pomiarów oporności elektrycznej. Przegląd Naukowy Inżynieria i Kształtowanie Środowiska, 18(4), 48-56.

Lu, N., Godt, J. (2008). Infinite slope stability under steady unsaturated seepage conditions. Water Resources Research, 44, W11404, DOI: 10.1029/2008WR006976
Lu, N., Griffiths, D.V. (2004). Profiles of steady-state suction stress in unsaturated soils. Journal of Geotechnical and Geoenvironmental Engineering, 130, 10, 1063-1076, DOI: 10.1061./(ASCE)1090-0241(2004)130: 10(1063)

Merritt, A.J., Chambers, J.E., Wilkinson, P.B., West, L.J., Murphy, W., Gunn, D., Uhlemann, S. (2016). Measurement and modelling of moisture-electrical resistivity relationship of fine-grained unsaturated soils and electrical anisotropy. Journal of Applied Geophysics, 124: 155-165

Pařílková, J., Zachoval, Z., Gruchot, A., Zydroń, T. (2018). Application of the electrical impedance spectrometry method for monitoring filtration phenomena on the example of Karolinka earth dam. Acta Sci. Pol. Formatio Circumiectus, 17(1), 163-177, DOI: http://dx.doi. org/10.15576/ASP.FC/2018.17.1.163.

Pazdro, Z., Kozerski, B. (1990). Hydrogeologia ogólna. Warszawa: Wyd. Geol.

PN-88/B-04481:1988. Grunty budowlane. Badania próbek gruntu. Warszawa : Polski Komitet Normalizacji, Miar i Jakości.

PN-EN ISO 14688-2:2006. Badania geotechniczne. Oznaczanie i klasyfikowanie gruntów. Część 2: Zasady klasyfikowania. Warszawa: Polski Komitet Normalizacyjny.

PN-CEN ISO/TS 17892-3: 2004. Badania geotechniczne. Badania laboratoryjne gruntów. Część 3: Oznaczanie gęstości właściwej - Metoda piknometru. Warszawa: Polski Komitet Normalizacyjny.

PN-CEN ISO/TS 17892-4: 2004. Badania geotechniczne. Badania laboratoryjne gruntów. Część 4: Oznaczanie składu granulometrycznego. Warszawa: Polski Komitet Normalizacyjny.

Van Genuchten, M.T. (1980). A closed form equation for predicting the hydraulic conductivity of unsaturated soils. Soil Science Society American Journal, 44, 892-898 .

Vanella, D., Cassiani, G., Busato, L., Boaga, J., Barbagallo, S., Binley, A., Consoli, S. (2018). Use of small scale electrical resistivity tomography to identify soil-root interactions during deficit irrigation. Journal of Hydrology, 556, 310-324.

Yilmaz, S., Koksoy, M. (2017). Electrical resistivity imaging and dye tracer test for the estimation of water leakage paths from reservoir of Akdeğirmen Dam in Afyonkarahisar, Turkey. Environmental Earth Sciences, 76, 829, DOI: https://doi.org/10.1007/s12665-017-7174-8.

Zawisza, E., Klimek, K. (2016). Wodoprzepuszczalność gruntów skarpy abrazyjnej zbiornika Czorsztyn-Niedzica. Acta 
Sci. Pol. Formatio Circumiectus 15(4)2016, 395-407. DOI: http://dx.doi.org/10.15576/ASP.FC/2016.15.4.395

Zawadzki, Ł. (2015). Wpływ właściwości gruntu na oporność elektryczną. Inżynieria Morska i Geotechnika, 3, $233-237$.
Zieher, T., Markart, G., Ottowitz, D., Römer, A., Rutzinger, M., Meiß1, G., Geitner, C. (2017). Water content dynamics at plot scale - comparison of time-lapse electrical resistivity tomography monitoring and pore pressure modeling. Journal of Hydrology, 544, 195-209.

\section{ZASTOSOWANIE METODY SPEKTROMETRII IMPEDANCYJNEJ DO MONITOROWANIA PRZEPŁYWU WODY W GRUNCIE NIENASYCONYM}

\section{ABSTRAKT}

\section{Cel pracy}

Celem badań było określenie wrażliwości metody spektrometrii impedancyjnej (EIS) na zmiany oporności elektrycznej ośrodka gruntowego wywołane infiltracyjnym przepływem wody.

\section{Materiak i metody}

Badania przeprowadzono dla dwóch gruntów mineralnych - niespoistego - piasku drobnego i spoistego piasku grubego pylastego. Zakres badań obejmował określenie podstawowych właściwości geotechnicznych obydwu gruntów (współczynnik filtracji, charakterystykę retencyjną) oraz badania infiltracji wody w pionowej kolumnie gruntowej. Badania te obejmowały pomiary zmian oporności elektrycznej ośrodka gruntowego, które porównano z obserwaScjami położenia fronu zwilżenia oraz z obliczeniami numerycznymi przepływu wody przez grunt. Badania infiltracji przeprowadzono dla trzech próbek gruntu. W pierwszym przypadku była to próbka piasku średniego, drugą próbkę stanowił piasek gruby pylasty, a w przypadku trzeciej próbki, dolną jej część stanowił piasek średni, a górną piasek gruby pylasty.

\section{Wyniki i wnioski}

Wyniki przeprowadzonych badań rezystancji elektrycznej gruntów poddanych procesowi infiltracji w pionowej kolumnie potwierdziły istotny wpływ obecności wody w ośrodku gruntowym na jego przewodność elektryczną. Wykazano, że zmiana wilgotności gruntu od stanu powietrznie-suchego do pełnego nasycenia powoduje redukcję rezystancji gruntu o prawie trzy rzędy wielkości. Wyniki badań wykazały stosunkowo dobrą zbieżność pomiędzy obserwowanym położeniem frontu zwilżenia, a zmierzonymi wartościami rezystancji gruntu potwierdzając tym samym przydatność testowanej metody pomiarowej dla potrzeb monitoringu obiegu wody w ośrodku gruntowym.

Stowa kluczowe: infiltracja, grunt, spektrometria impendacyjna 